\title{
Threats to Biodiversity Resources in Badagry Local Government area of Lagos State
}

\author{
Jenyo-Oni Adetola ${ }^{1}$, Adepoju Mary A ${ }^{2}$. \\ ${ }^{I}$ (Department of Wildlife and Fisheries Management, University of Ibadan. Ibadan Nigeria) \\ ${ }_{2}^{2}$ (Department of Wildlife and Fisheries Management, University of Ibadan. Ibadan Nigeria)
}

\begin{abstract}
Biodiversity constitute the source of all our food, much of our raw materials, a wide range of goods and services and genetic materials for agriculture, medicine, industry and commerce worth billions of dollars per year. For Nigeria and other African countries, biodiversity is of critical importance to our survival as our livelihood is dependent on having free and open access to a great variety of biological resources for food, fuel, medicine, housing materials, farm implement and economic security.

Data was collected using three methods: Reconnaissance and direct observation, use of questionnaires and Oral interview. Administration of one hundred and twenty (120) structured questionnaires in eight (8) randomly picked coastal communities of Badagry Local Government of Lagos State, oral interview was also conducted to get information from the residents and direct observation of resource availability, resource management status and threats to biodiversity in the selected communities were carried out. The data collected for the study was analyzed using descriptive and inferential statistics.

The evaluation of the major biodiversity resource available across the various community of study reveals that various species of fish: cat fish (Clarias gariepinus), obokun, (chrysythys nigrodigitatus), tilapia (Oreochromis niloticus), prawns (Peanus notatus), Raffia palm (Raffia vinifera), Coconut (Cocos nucifera) and Rhizophora spp are more abundant. The opinions of the respondents on threats to biodiversity revealed that 46.7\% believed there are no threats and $45.8 \%$ believe otherwise while $7.5 \%$ did not respond. Respondents' view is dependent on community at $\mathrm{P}$-value $0.00041(\mathrm{P}<0.05)$ and not dependent on sex at $\mathrm{P}$-value of 0.63678.
\end{abstract}

Keywords - Badagry Nigeria, Biodiversity Resource, Threats

\section{Introduction}

Natural resources - land, water, vegetation and biodiversity are the primary source of people's livelihoods in poor countries. Consequently, natural resources are vitally important for poverty reduction and development. In many developing countries, the loss and degradation of natural resources is continuing unabated, with dire consequences for the rural population's livelihoods. A vicious circle of poverty and environmental degradation arises, which not only complicates local development but has further dramatic global impacts (Emerton, et al., 1998 [1]).

Biodiversity, reduced to its simplest essentials, means biological diversity. It encompasses all varieties of life forms on earth, which provide the building blocks for human existence and it makes for a balanced environment. It refers to the life forms on earth and include the millions of plants, animals and micro-organisms, the genes, they contain as well as the intricate ecosystem they help built into the living environments. Biodiversity has three fundamental and hierarchically related levels of biological organization namely: Genetic Diversity, Specie Diversity and Ecosystem Diversity, and it have become a widespread practise to define biodiversity based on these (Emma-Okafor et al, 2010 [2]). Biodiversity yields many sustainable development benefits, yet, paradoxically human society continue to undermine this valuable resource base, instigating large scale biodiversity losses and species extinction (Swing-land, 2003 [3]).

Environmentalists, therefore, concede that biodiversity is critical to the maintenance of a healthy environment, since its role in meeting human needs directly, as well as maintaining the ecological process is enormous. They contend that biodiversity not only provides direct benefits such as food, medicines and energy, but also affords human a life support system. "It is also responsible for mitigating pollution, protecting watersheds and combating soil erosion," they add.

Biodiversity, no doubt, plays the crucial role of acting as a buffer against excessive weather variations, which are ordinarily beyond human control and catastrophic. Biodiversity has always been viewed in isolation as falling outside social, political and economic spheres. However, the importance of biodiversity conservation is critical to all. Biodiversity is not only about greenness and plants and animals, it is also about the economy and the lives of people at community level. Environmental experts lament that the environment has suffered a large scale abuse worldwide, particularly in Africa, as a result of pollution, oil exploration activities, mining, war and other related human activities. 
Biodiversity is decreasing at an alarming rate due to the impact of the increasing human population, rising natural resource consumption rates and inequity in the ownership, management and flow of benefits from both the conservation and use of biological resources (McNeely et al. 1995 [4]).

The warning by the Convention on Biological Diversity (CBD) that biodiversity is facing some threat on the planet Earth underscores the importance of the global initiative. "Species have been disappearing at up to 1,000 times the natural rate, and this is predicted to rise dramatically.

For Nigerians and indeed other Africans, biodiversity is of critical importance to our survival. This is because our livelihood is dependent on having free and open access to a great variety of biological resources for food, fibre, fuel, medicines, housing materials and economic security. Subsistence and commercial agriculture, livestock production, logging and fishing which accounts for the bulk of employment, economic outputs and even export earnings in many parts of the country relies on the continued productivity of the local ecosystems. What is more, majority of Nigerians particularly in rural areas depend on herbal remedies for their primary health care while wood in the form of fuel wood and charcoal represent by far the largest energy source in both rural and urban areas of the country. Housing and crafts and farming implements as well depend on local plant materials.

To Nigerians therefore, biodiversity represents an indispensable resource endowment. The food we eat, the fuel with which food is cooked and the export products that generate foreign exchange, they are all dependent on the continued health and productivity of our ecological system, conservation of which is very essential.

\section{Study Area}

The study was carried out in the coastal wetland area of Badagry Local Government in Lagos State. Lagos, currently the fifth largest city in the world, is the foremost manufacturing and port city in West Africa and the hub of business and economic development in Nigeria (LMDGP, 2006 [5]).

The State is located on the south-western part of Nigeria on the narrow coastal flood plain of Bight of Benin. It lies approximately within longitude $2^{\circ} 42^{\prime} \mathrm{E}$ and $3^{\circ} 42^{\prime} \mathrm{E}$ and stretches between Latitude $6^{\circ} 22^{\prime} \mathrm{N}$ and $6^{\circ} 42^{\prime} \mathrm{N}$. It directly connects with Nigeria's $960 \mathrm{~km}$ of coastline bordering the Atlantic Ocean in the Gulf of Guinea, a maritime area of $46,500 \mathrm{~km}^{2}$ with depth of up to $50 \mathrm{~m}$ and an Exclusive Economic Zone of 210,900 $\mathrm{km}^{2}$ (World Resources, 1990 [6]).

Lagos State is bounded in the North and East by Ogun State of Nigeria, in the West by the Republic of Benin, and in the South by the Atlantic Ocean. It has five administrative divisions of Ikeja, Badagry, Ikorodu, Lagos Island and Epe. Territorially, Lagos State encompasses an area of 358,862 hectares or $3,577 \mathrm{sq} . \mathrm{km}$. Badagry local government comprises of about eighty three (83) communities of which 8 communities were randomly selected.

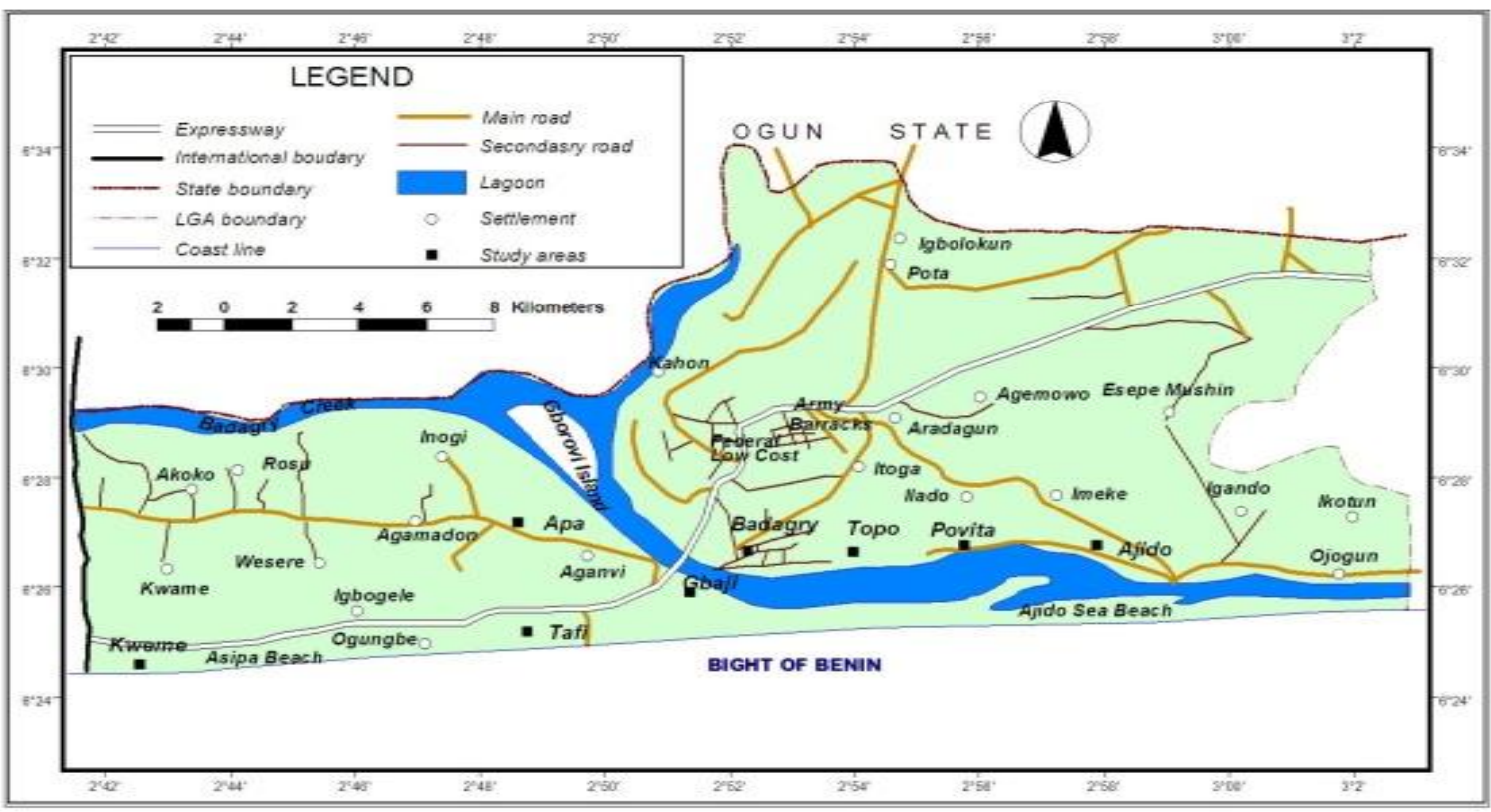

Figure 1: Map of Badagry Local Government 


\subsection{Methods Of Data Collection}

Three methods were used for the data collection for this study:

- Reconnaissance and direct observation

- Administration of questionnaire

- Oral interview

3.1 Reconnaissance and direct observation: A preliminary survey was done to identify the communities of study and also to assess some of the biodiversity resources available. Photographs of these resources and identified threats were taken.

3.2 Questionnaire: a total number of one hundred and twenty (120) structured questionnaires were randomly administered in the eight randomly selected communities out of seventy-nine (79) communities (15 questionnaires per community) among the residents. Badagry Local Government is divided into two divisions; Badagry Central and Badagry West. Four coastal communities: Badagry, Topo, Povita, Ajido, Apa, Tafi, Kweme and Gbaji were picked from each of the divisions as the population sample. Assistance was given to people who had difficulty in reading and writing. The questionnaire was designed to gather demographic information of the respondents as well as to address the key objective of this research work by :

3.2.1 Gathering information on the available biodiversity resources and their uses

3.2.2 Threats to the resources

3.2.3 Government and non-governmental involvement in ensuring sustainable utilization of these resources in the various communities of study.

3.2.4 Also, to know the Prospect of Integrated Approach to achieving sustainable utilization of the biodiversity resources by the respondents' willingness to work together to achieve this.

3.3 Oral interview: questions were asked orally to get information from the residents on their traditional ecological knowledge of the biodiversity resources. The residents were encouraged to respond as honestly as possible; the questions were asked one on one. Their response highlighted important issues of interest regarding to threats to biodiversity resources and their knowledge and practise of sustainable utilization of the identified resources

\subsection{Statistical Analysis}

The data collected for the study were analysed using descriptive and inferential statistics. The descriptive statistics included; frequency analysis, graphical analysis, charts, cross tabulation and percentages; while the inferential statistics include; chi square which was done using SPSS-PC software. The level of significance value chosen was $\mathrm{p}=0.05$.

\section{Result}

The result of threats to biodiversity in the various communities is presented in Table 1 . The table reveals that in Tafi, $80 \%$ of the respondents are of the opinion that there are no threats to biodiversity in the community while $20 \%$ believed otherwise. In Badagry, $20 \%$ believed there are no threats, $73.3 \%$ believed there are threats while $6.7 \%$ did not indicate their opinion. In Ajido, $26.7 \%$ indicated no threats, $53.3 \%$ indicated there are threats while $20 \%$ did not give their opinion. In Kweme, $33.3 \%$ believed there is no threat while $66.7 \%$ believed the biodiversity is not threatened. In Gbaji, $73.3 \%$ indicated no threats while $6.67 \%$ indicated threats. In Topo, $46.7 \%$ indicated no threats while $53.3 \%$ indicated there are threats. In Povita, $26.7 \%$ of the respondents indicated there are no threats, $66.7 \%$ indicated there are threats while $6.67 \%$ did not give their opinion. In Apa, $66.7 \%$ believed there are no threats, $26.7 \%$ indicated there are threats while $6.67 \%$ of the respondents did not give any indication of threats to biodiversity in the community. At $\mathrm{P}$-value $0.00041(\mathrm{P}<0.05)$, threats to biodiversity is significantly dependent on each of the community, but not significantly dependent on sex at $\mathrm{P}$ value of 0.63678 .

The frequency distribution of respondents' view across the communities studied is presented in Figure 1. Some of the identified threats across almost all the communities happen to be the activity of sand dredgers and scoopers, their scooping activities destroys fish breeding ground and as shown in plate 1and 2, destroys land pattern thereby reducing resource availability such as coconut, raffia palm, etc. this is mostly common in Topo, Ajido and Povita. In Povita and Topo, the residents are scared of possible flooding in future due to the fact that the scooping activity is eating deep into the community. Also due to increased population and infrastructure, raffia palm that used to be abundant in Topo is diminishing and the residents have resolved into having an artificial plantation for it as shown in Plate 3 which is a good sign of sustainable use of the resource. Another threat that was observed is the presence of water hyacinth (Eichhornia crassipies). From the respondents' 
traditional ecological knowledge, it was first noticed in the year 1983 and did not pose any threat until later years. When the respondents' were asked of the method of control use for this aquatic plant, it was discovered that they allow it grow until the dry season when the water becomes salty and hence dries up the plant.

Table 1: Observed Frequencies on threats to biodiversity in the communities of study

\begin{tabular}{lllcll}
\hline & & & Notice & & Row \\
& No Threats & $\%$ & Threats & $\%$ & Totals \\
\hline Community & 12 & 80 & 3 & 20 & 15 \\
Tafi & 12 & 20 & 11 & 73.33 & 14 \\
Badagry & 3 & 26.67 & 8 & 53.33 & 12 \\
Ajido & 4 & 33.33 & 10 & 66.67 & 15 \\
Kweme & 5 & 73.33 & 1 & 6.67 & 12 \\
Gbaji & 11 & 46.67 & 8 & 53.33 & 15 \\
Topo & 7 & 26.67 & 10 & 66.67 & 14 \\
Povita & 4 & 66.67 & 4 & 26.67 & 14 \\
Apa & 10 & 46.67 & 55 & 45.83 & 111 \\
Totals & 56 & & 0.00041 & & \\
P-value & & & & & \\
SEX & & 43.33 & 28 & 46.67 & 54 \\
M & 26 & 50 & 27 & 45 & 57 \\
F & 30 & 46.67 & 55 & 45.83 & 111 \\
Totals & 56 & & $0.63678 \mathrm{~ns}$ & & \\
P-value & & & &
\end{tabular}

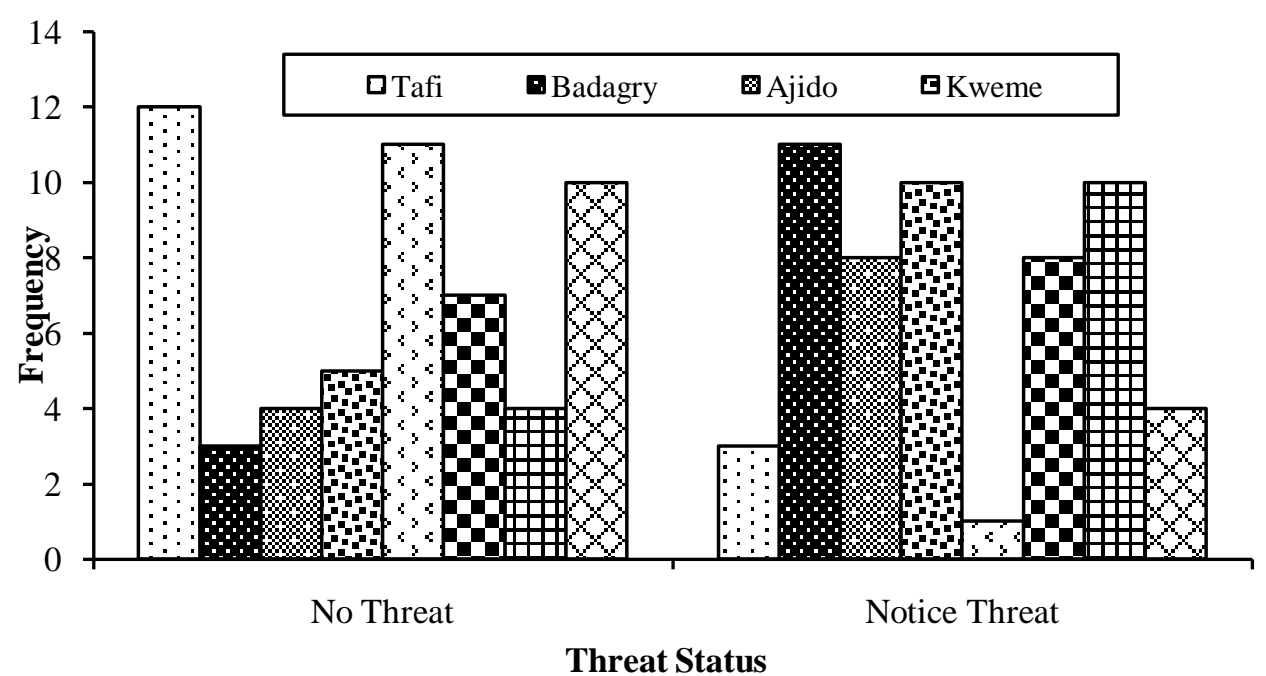

Figure 2: Frequency distribution of the respondents' view on whether threat to biodiversity is noticed across the communities studied. 


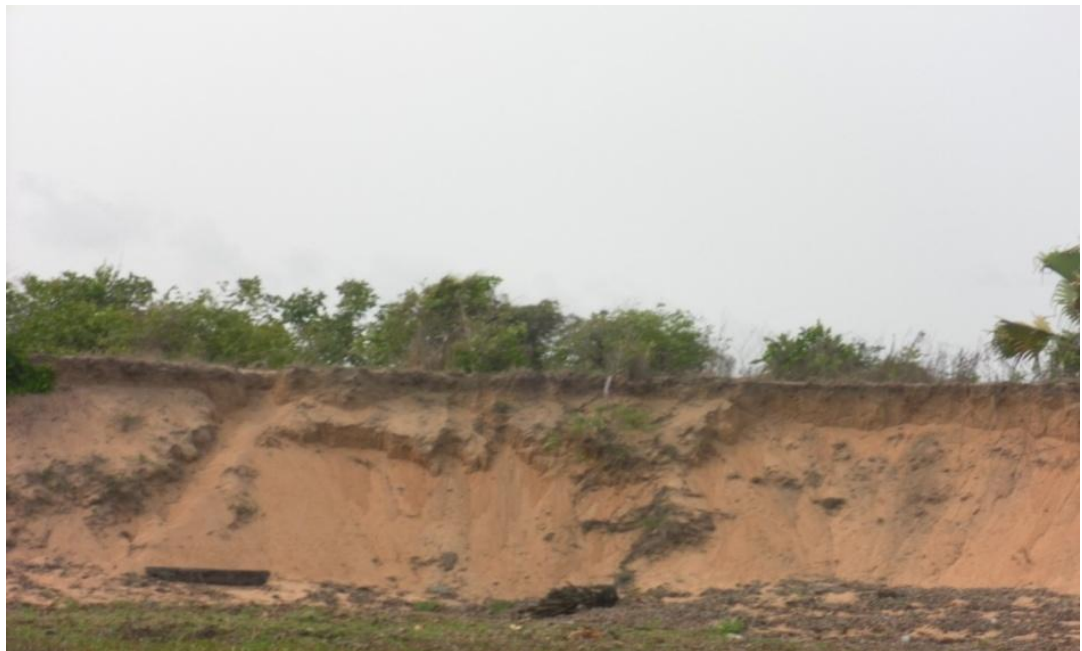

Plate 1: Shore Erosion: effect of sand dredging on the environment in Topo Community

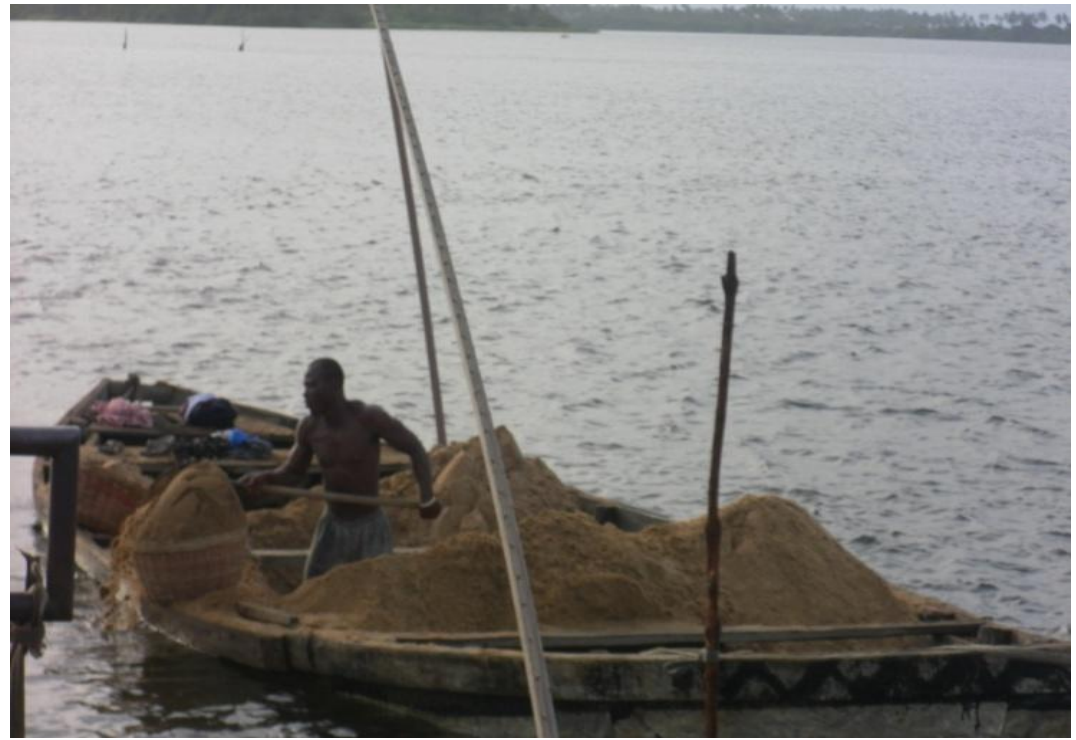

Plate 2: Sand being dredged out of a water body in Ajido Community

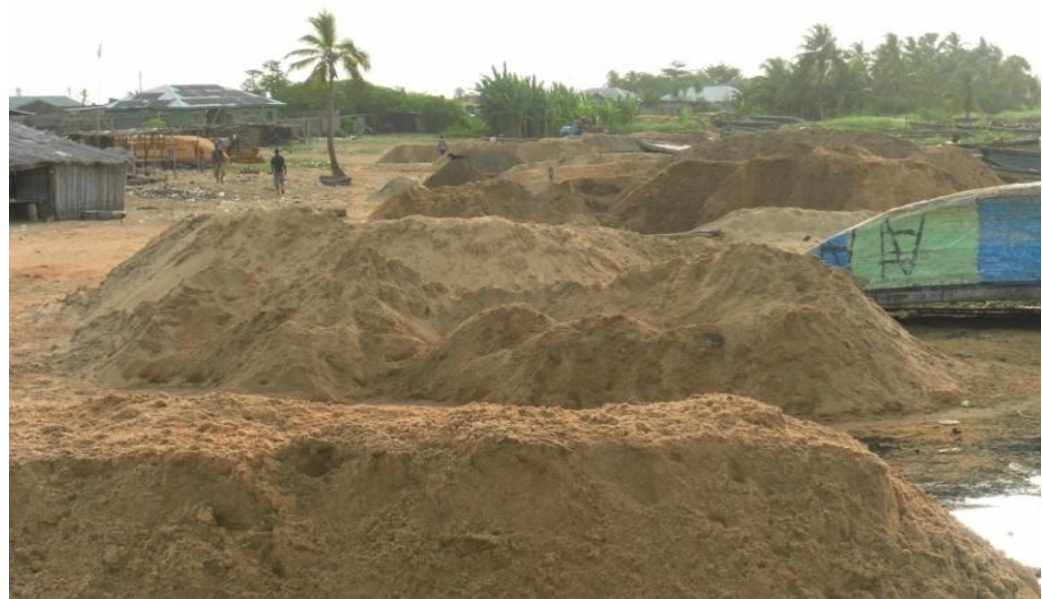

Plate 3: Sand dredged out of a water body in Ajido Community 


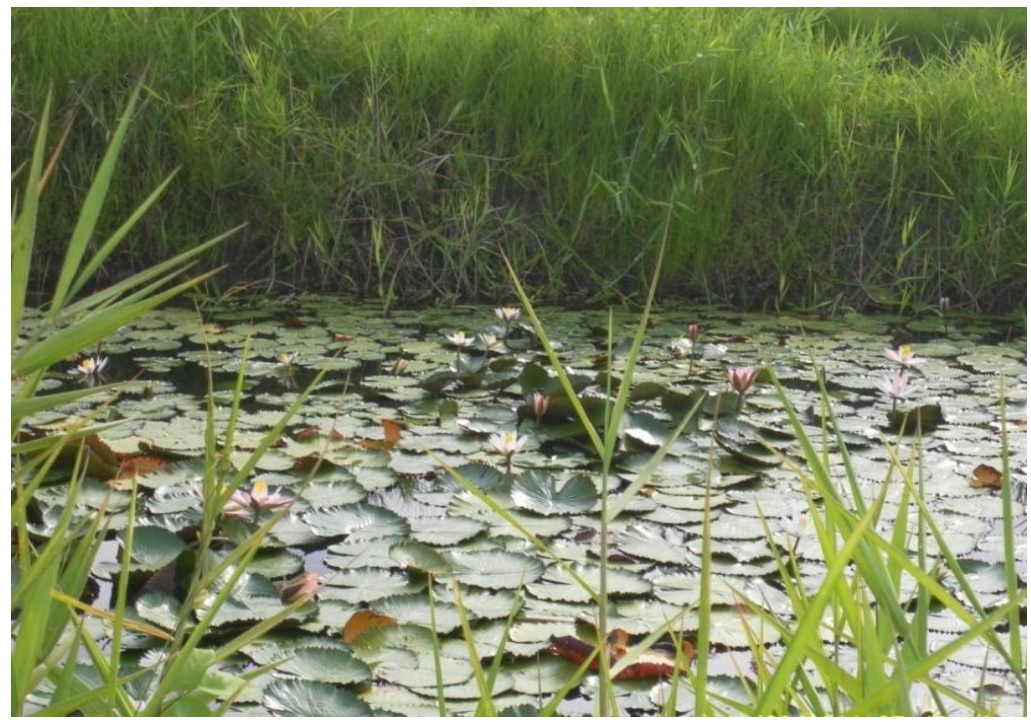

Plate 4: Aquatic weeds, a major threat to aquatic resources in Povita

\section{Conclusion}

Badagry local government comprises of about eighty three (83) communities rich in biodiversity. The commonest of these biodiversity resources are Cocos nucifera (coconut), raffia palm (Raffia vinifera), water resources and Rhizophora spp. The commonest of the water resources are Clarias gariepinus (catfish), Oreochromis niloticus (tilapia), Chrysichthys nigrodigitatus (obokun) and peanus notatus (prawn). Based on the respondents' traditional ecological knowledge, it was discovered that some of the resources that used to be abundant have greatly diminished.

The identified threats to biodiversity resources across the communities is the activity of sand dredger and scooper which needs to be checked to prevent permanent damage to the ecosystem and flooding of communities especially Povita and Topo.

Biodiversity constitute the source of all our food, much of our raw materials, a wide range of goods and services and genetic materials for agriculture, medicine, industry and commerce worth billions of dollars per year. For Nigeria and other African countries, biodiversity is of critical importance to our survival as our livelihood is dependent on having free and open access to a great variety of biological resources for food, fuel, medicine, housing materials, farm implement and economic security.

\section{References}

[1] Emerton, L., Iyango, L., Luwum, P. and Malinga, A. The Present Economic Value of Nakivubo Urban Wetland, Uganda. IUCN The World Conservation Union, Eastern Africa Regional Office, Nairobi and National Wetlands Programme, Wetlands Inspectorate Division, Ministry of Water, Land and Environment, Kampala. 1998 ,30pp.

[2] Emma-Okafor, Lilian Chinenye Ibeawuchi, Izuchukwu Innocent, Obiefuna Julius Chiedozie, Biodiversity Conservation for Sustainable Agriculture in Tropical Rainforest of Nigeria. New York Science Journal 2010; Vol.3(1),Pp 81-84.

[3] Swing land IANR (2003). Capturing carbon and conserving Biodiversity. "The market approach. Earth scan Publications LTD.

[4] McNeely J. A., M. Gadgil, C. Levèque, C. Padoch and K. Redford, Human influences on biodiversity. In V. Heywood (ed.), Global Biodiversity Assessment, 711-821. 1995 Cambridge: Cambridge University Press.

[5] Soyombo O., LMDGP ( Lagos Metropolitan Development and Governance Project) Main Report Lagos State Urban Upgrading Project Confirmation Survey 2006

[6] World Resources: A Report by the World Resources Institute in Collaboration with UNEP and UNDP. Oxford University Press, NewYork, USA 1990. p. 383.

[7] CBD (Conservation of Biodiversity) Global Biodiversity Outlook. The 2010 Biodiversity Target: Establishing Current Trends.2006 Pp 34-36. 